\title{
Study on the Spread and Cultural Self-confidence of Chinese Traditional National Culture under the New Media Environment
}

\author{
Xiaoli Su, Xuehui Wu
}

Nanchang Institute of Science \&Technology,Nanchang 330108,China

\begin{abstract}
Keywords: Four self-confidence; Cultural self-confidence; Chinese traditional national culture; The new media
\end{abstract}

\begin{abstract}
Xi Jinping pointed out that stay true to the mission, continue to move forward, we must continue to strengthen the four self-confidence, no matter at what time, all to a profound understanding of the cultural self-confidence is the cornerstone of a national culture inheritance and dissemination, without cultural self-confidence, the inheritance and promotion of a country's traditional culture will lose the direction, so we must deal with the relationship between traditional culture and cultural self-confidence.
\end{abstract}

\section{The status and role of Chinese traditional culture communication and cultural self-confidence in the new media environment}

Every nation has its own unique traditional culture, it is the foundation and the blood nation thrive; every nation's traditional culture is complex, from the specific historical coordinates and the corresponding evaluation standards, its contents are excellent and backward cent. Chinese traditional culture is the soul of the Chinese nation and the soul of the culture. Standing in the height of the times, based on Marx's standpoint, viewpoint and method, the content of Chinese traditional culture can also be distinguished from the excellent and backward. Generally speaking, the excellent traditional culture refers to the essence of Chinese traditional culture, which has passed through the vicissitudes of life and has been inherited. Excellent traditional culture is beyond the era limitation, reflect the characteristics of Chinese civilization eternal value to a great extent, to the phase and the direction of development of social history.

The Chinese traditional culture, with human nature as the source of attention to human nature kind, the end with the solemn speech of harmony and appropriateness, advocating self-cultivation, pity the orphans and widows, respect the old and love the young and anti evil, help the weak and heavy righteousness, patriotic and ideological value, emphasis on human and nature, the harmonious coexistence of human and society. The characteristics of Chinese traditional culture: pass on from generation to generation, ethnic flavor, have a long historical standing, broad and profound. Cultural self-confidence is the premise and powerful guarantee for spreading Chinese traditional culture.

\section{How to inherit Chinese traditional culture and establish the cultural self-confidence}

Under the new media environment of Chinese traditional culture inheritance and establish cultural self-confidence, its purpose is to adapt ancient forms for present. There are several kinds of forms: Such as calligraphy interview, when the program goes deep into the historical background of Chinese traditional calligraphy, calligraphy origin, calligraphy inheritance, aesthetic appreciation, 
etc.; Such as historical and cultural relics, restore historical scene, political style, economic analysis connotation and so on; Such as primary school students to learn the traditional culture, not only to read classics, appreciate their ideas Han and charm, but also to combine today, learn nutrition, understand the truth of life; Various forms, the event itself contains traditional factors, or events can be excavated; System factors, or events can be analyzed by traditional elements, etc.. In the program, one or more of them can be combined together. Practice has proved that, the integration of traditional Chinese culture can increase the sense of the program.

\section{How to develop Chinese traditional culture and enhance the cultural self-confidence}

In order to develop Chinese traditional culture and enhance the cultural self-confidence, In my opinion, we should do the following:

The combination of traditional culture and the present. Traditional cultural propaganda, focusing on propaganda, the breakthrough point is today. This combination should be organic, natural and effective. Avoid their general.

The combination of traditional culture and the times. Any publicity will have the era of branding. As a media person, should in the torrent of the times, the realization of the Chinese dream, and the inheritance of Chinese biography unity of culture.

Traditional culture must absorb new nutrition. To maintain a strong vitality of a nation's culture, it is necessary to continue to absorb foreign nutrition. Similarly, Chinese traditional culture must absorb the essence of other excellent national culture and enrich its cultural connotation.

\section{The responsibility and mission of Chinese traditional culture communication under the new media environment.}

In order to fulfill The responsibility and mission of Chinese traditional culture communication. This is a complex system engineering, which needs to be improved in many fields. We should do the following:

Learn to upgrade. Only do have the goods in the belly, when there will be an inspired passage. Only a lot of things in the repository, the media propaganda resources are rich.

Natural grafting, self-regardless. The media to promote Chinese traditional culture, the Chinese traditional culture grafted to the media, merge into media. The process should be natural, just right, do not draw a forced analogy 。

Advancing with the times. Many of the ideas of the Chinese traditional culture, such as "harmony between human and nature" of the universe, the value of it contains factors for modern people, those should inherit and use, it contains is a universal law of harmonious development, everything in the universe is the opposite, the overall concept of a unified concept, but also the development of the concept of people, this concept has important reference significance for the construction of ecological civilization.

Improve the realm, guide the audience to abide by the traditional Chinese culture.

Praise highly noble values. The state pays more and more attention to the return and establishment of national traditional values. build up the spirit and build up the moral fashion, so that our country, our nation and our people will be stronger in the mind and spirit.

Improve value judgment. To enhance the value judgment of the people, to persist from childhood and into the whole process of national education, through school education, family education and social education of the various links and aspects, with excellent traditional culture as the foundation, to promote Chinese culture essence, moral essence, strive for culture, writing 
education, enhance the value judgment.

Enhance the sense of moral responsibility. The world is developing, but the morality is getting worse and worse. This is the problem that the whole world should be concerned. As the media practitioners, should have more such responsibility and consciousness, pay more attention to people's spiritual level of the trend and development, guidance and intervention of people's moral tendency. The spread and practice of traditional culture, to answer people's anxiety and confusion, soothe the soul of cultural heritage, enhance national self-confidence, the education of future generations, to regain the essence of national culture, constructing Chinese traditional moral value system.

Combined with the times, brighten the Chinese traditional culture. In today's era, to promotion of Chinese traditional culture should do six words: inheritance, development, carry forward. The first is to inherit, it is to enter the traditional culture. When we really approached, understand, learn and practice the traditional culture, the real will be issued from the bottom of my heart, I am proud, I am Chinese. The second is the development, in the development of inheritance, in the present pregnant with new vigor and vitality. The last is carry forward, Chinese traditional culture is the precious wealth that we have is the real advantage of Chinese based on the nations of the world, we have the responsibility and obligation to make good use of the media platform, the traditional Chinese culture better spread and carry forward.

\section{Adherance to cultural self-confidence should correctly deal with traditional culture and foreign culture}

The Chinese characteristic socialism cultural self-confidence is rooted in the fertile soil of Chinese traditional culture nurtured by the 5000 years of civilization development. At the same time, generations of Chinese people in our traditional culture continue to keep pace with the times, the inheritance and development of the excellent Chinese traditional culture broad and profound, the cultivation of the Chinese nation, emotional value and common ideal, provides rich nourishment and powerful spiritual force, on behalf of the Chinese nation unique spiritual identity and cultural superiority. As general secretary Xi Jinping pointed out: Chinese culture into the Chinese people's bone marrow, it is the culture of DNA. The great rejuvenation of the Chinese nation requires the development and prosperity of Chinese culture as a condition.

Strengthen cultural self-confidence, by no means stand upon one's pantofles, do not adhere to close the country to international intercourse,but to stick to the excellent Chinese culture at the same time, adhere to the outside world. The scientific treatment of foreign culture. Chinese culture has a strong inclusive, fully inclusive and equitable, all rivers run into sea, continue to learn from outstanding foreign culture, and creatively into their own things, it is the proper meaning of Chinese culture development strategy. We must not only adhere to the principle of Marx as the mainstream ideology of guidance, but also for a variety of useful ideas, school, schools are leading to inclusive development; absorb all the excellent heritage of human civilization, and consciously resist the invasion of western wrong thought misleading.

\section{Conclusion}

To realize the Chinese dream, we must fully tap and absorb the valuable resources of the Chinese excellent traditional culture. The Communist Party of China has always been to carry forward the fine traditional Chinese culture as its mission, and continue to give excellent traditional culture to a new era. Generation after generation of Chinese Communists in the struggle to achieve the dream of 
China, it will be a lot of noble quality and the essence of traditional Chinese culture to the unprecedented height of history. At the same time, Chinese Communists to highly theoretical consciousness and cultural confidence, continue to promote the interaction of excellent traditional culture and advanced socialist culture fusion, traditional culture through the creative transformation become the inexhaustible source of advanced socialist culture China characteristics, the cultural foundation of national rejuvenation China dream has been consolidated.

At the same time, we should also see clearly that in the face of new tasks and new requirements China dream during the new period, our excellent Chinese traditional culture resources mining and learn there are still significant gaps and deficiencies, there are a lot of hard work to do, and have a brilliant future broad space. We should continue to use Marx's world outlook, values and methodology of Chinese traditional culture, further detailed analysis and in-depth mining, its essence, to its dregs, to do more to make the past serve the present, the excellent traditional culture of fine rich, more diverse services in China China dream; promote to adapt, the excellent traditional culture and contemporary society in harmony with the modern civilization and world culture development trend is consistent, make excellent traditional culture while maintaining the distinctive national features and rich spirit of the times, realize the times to serve the dual Chinese dream; face the dilemma facing the fine traditional culture of the loss of internal resources and the impact of foreign culture, more understandable to the interpretation and elucidation of the fine traditional culture to express and spread the excellent traditional culture vividly. In short, we should have to learn from the excellent traditional culture to achieve highly conscious spiritual to strength Chinese dream, and then put the excellent traditional culture into a powerful force to realize the great dream Chinese, improve the level of our cultural self-confidence.

\section{References}

[1] Mengzi H E, Hong X. On the Position and Function of Core Values in the Construction of National Cultural Soft Power[J]. Studies in Sociology of Science, 2015, 6(1).

[2] Tan Z J. Thought on the Research of the "Soft Power" and the Construction of National Cultural Security System[J]. Oriental Forum, 2009.

[3] Gui-Rong P. Rational Thought on Enhancing the National Cultural Soft Power[J]. Journal of Heilongjiang College of Education, 2008.

[4] Tagami K, Nochi K, Moribayashi H, et al. Rational Thought on Strengthening College Honest and Clean Government Cultural Construction[J]. Journal of Southwest University for Nationalities, 2006, 11(2):205-216.

[5] Pei Q. On the Path of Enhancing the Soft Power of Red Culture in the Perspective of Cultural Confidence[J]. Journal of the Party School of Shengli Oilfield, 2016.

[6] Lepori B, Usher J, Montauti M. Budgetary allocation and organizational characteristics of higher education institutions: a review of existing studies and a framework for future research[J]. Higher Education, 2013, 65(1):59-78.

[7] Karadima O. Management Information Systems for Faculty Allocations in Institutions of Higher Education: A Case Study for the Universidad de Santiago de Chile.[J]. Case Studies, 1983:263. 